\title{
Speciation of Uranium and Plutonium From Nuclear Legacy Sites to the Environment: A Mini Review
}

\author{
Anna Yu. Romanchuk, Irina E. Vlasova and Stepan N. Kalmykov* \\ Department of Chemistry, Lomonosov Moscow State University, Moscow, Russia
}

The row of 15 chemical elements from Ac to Lr with atomic numbers from 89 to 103 are known as the actinides, which are all radioactive. Among them, uranium and plutonium are the most important as they are used in the nuclear fuel cycle and nuclear weapon production. Since the beginning of national nuclear programs and nuclear tests, many radioactively contaminated nuclear legacy sites, have been formed. This mini review covers the latest experimental, modeling, and case studies of plutonium and uranium migration in the environment, including the speciation of these elements and the chemical reactions that control their migration pathways.

Keywords: plutonium, uranium, migration, environment, speciation

\section{INTRODUCTION}

OPEN ACCESS

Edited by:

W. H. Eugen Schwarz,

University of Siegen, Germany

Reviewed by:

Nail M. Shavaleev, Independent Researcher, Ufa, Russia

Akitaka Ito,

Kochi University of Technology, Japan

${ }^{*}$ Correspondence:

Stepan N. Kalmykov stepan@radio.chem.msu.ru

Specialty section This article was submitted to Inorganic Chemistry,

a section of the journal

Frontiers in Chemistry

Received: 15 March 2020

Accepted: 17 June 2020

Published: 12 August 2020

Citation:

Romanchuk AY, Vlasova IE and Kalmykov SN (2020) Speciation of

Uranium and Plutonium From Nuclear Legacy Sites to the Environment: A Mini Review. Front. Chem. 8:630. doi: 10.3389/fchem.2020.00630
The discovery of the nuclear fissions of U-235 and Pu-239 led to the era of nuclear weapons development and nuclear energy production. The first national nuclear programs dealt with uranium separation from ore, U-235 enrichment, plutonium production, and fuel fabrication without considering the radiation safety and environmental protection. From the start of nuclear programs and up to the period of environmental awareness, 1940s to the 1980s, many nuclear sites were established worldwide that to this day are contaminated with uranium and plutonium (Rybalchenko et al., 2005; Novikov et al., 2006; Zachara et al., 2013). Every nuclear fuel production and waste reprocessing site in the 1940-1960s used surface or underground radioactive waste storage. Many countries adopted strategies for the remediation of contaminated sites, and in some cases, remediation has been started or even completed (Conradson et al., 2011). The speciation of radionuclides in contaminated sites has been studied, and recently new discoveries were made about the speciation of uranium and plutonium that were released into the environment as a result of accidents or in the course of daily operation. Sufficient time has passed since these sites were established to clarify the migration processes. Today, we have 60 years of data on nuclear test sites and 30 years of data on consequences of the Chernobyl nuclear power plant (NPP) accident. Analysis of these data may help us to better understand the environmental behavior of actinides.

We review the recent trends in the studies of the physics and chemistry of uranium and plutonium in the nuclear legacy sites and in laboratory experiments. Figures 1, 2 summarize the speciation of $\mathrm{U}$ and $\mathrm{Pu}$ and the migration pathways of $\mathrm{U}$ and $\mathrm{Pu}$ from the legacy sites into the environment.

\section{URANIUM}

Two main oxidation states of uranium, namely +4 and +6 , exist under natural geochemical conditions. In aqueous solutions, uranium is mainly present in its most mobile form the uranyl cation $\mathrm{U}^{\mathrm{VI}} \mathrm{O}_{2}^{2+}$, typically in the form of hydroxyl and carbonate complexes. The mobility 


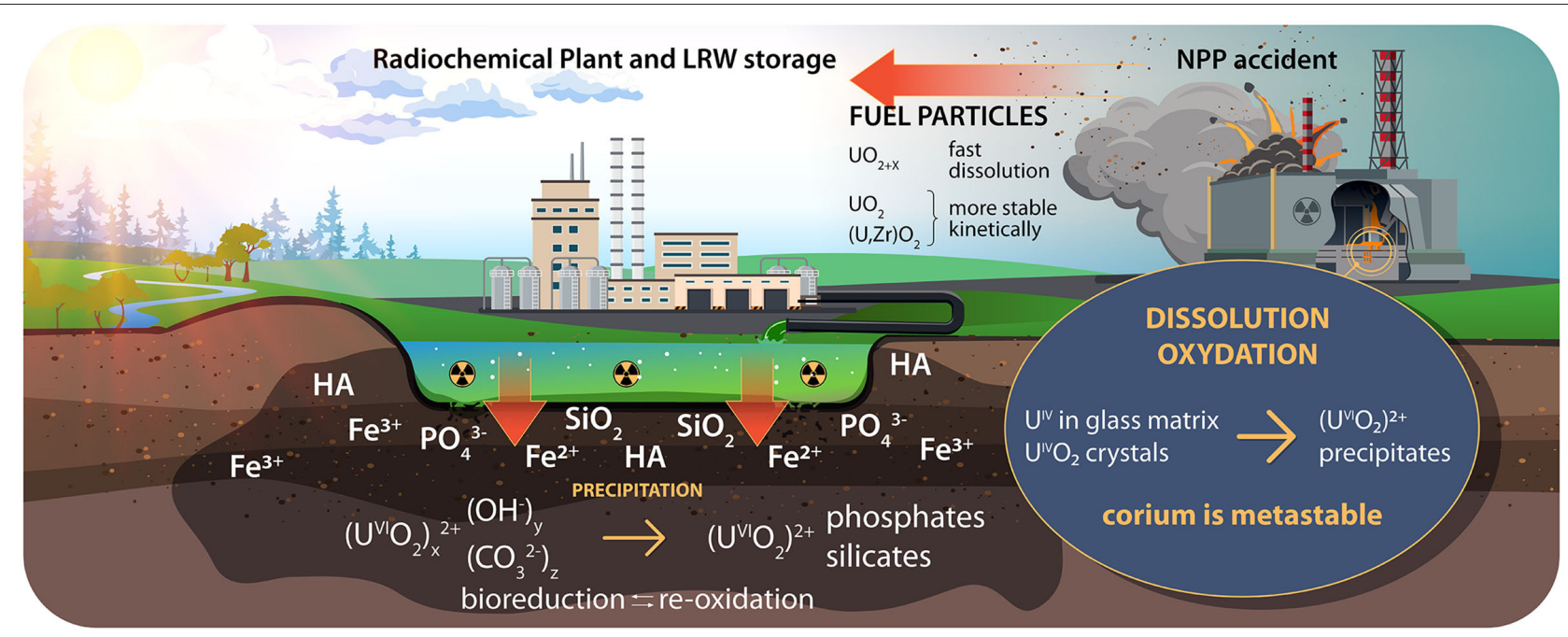

FIGURE 1 | U migration into the environment. NPP, nuclear power plant; LRW, liquid radioactive waste; HA, humic acid

of uranium depends on the redox conditions and the presence of cations $\left(\mathrm{Ca}^{2+}, \mathrm{Fe}^{2+}\right.$, and $\left.\mathrm{Fe}^{3+}\right)$, anions (carbonate, phosphate, and sulfate), silica, natural rock-forming minerals, organic substances, and microorganisms (Figure 1). In a reducing environment (oxygen-free conditions of deep underground disposals in the presence of microorganisms), uranium can transform into a less mobile form, U(IV). However, U(IV) may easily reoxidize if the conditions change. At the same time, uranium could be kinetically stabilized in "hot" particles. For example, as a result of accidental fallout (e.g., the Chernobyl accident), kinetically stable fuel particles were released into the environment, in which $\mathrm{U}(\mathrm{IV})$ was mainly in the form of $\mathrm{UO}_{2}$ (Figure 1).

For a long time, it was believed that pentavalent uranium does not occur in nature with a few exceptions since the cation $\mathrm{U}^{\mathrm{V}} \mathrm{O}_{2}^{+}$ is unstable in aqueous solution due to its disproportionation into $\mathrm{U}^{\mathrm{IV}}$ species and $\mathrm{U}^{\mathrm{VI}} \mathrm{O}_{2}^{2+}$ (Arnold et al., 2009). In addition, a technical difficulty occurred in detecting pentavalent uranium in the samples. The latest $\mathrm{U} \mathrm{L}_{3} \mathrm{X}$-ray absorption spectroscopy (XANES) study demonstrates $\mathrm{U}^{\mathrm{VI}}$ reduction to $\mathrm{U}^{\mathrm{V}}$ in the presence of $\mathrm{Fe}^{\mathrm{II}} / \mathrm{Fe}^{\mathrm{III}}$ oxides and oxy-hydroxides (Boland et al., 2014; Marshall et al., 2015). Three valence states of uranium, $\mathrm{U}(\mathrm{IV}), \mathrm{U}(\mathrm{V})$, and $\mathrm{U}(\mathrm{VI})$, could be distinguished via $\mathrm{U} \mathrm{M}_{4}$ edge high-energy resolution X-ray absorption spectroscopy (HERFDXANES) in a sample with a $U$ concentration range of 1,00010,000 ppm (Pidchenko et al., 2017; Roberts et al., 2017). Therefore, $\mathrm{U}(\mathrm{V})$ should also be considered in the environment.

\section{Immobilization of $\mathbf{U}$}

Uranium leakage from near-surface and surface liquid radioactive waste (LRW) storage facilities (Figure 1) as well as from underground deep disposals into permeable formations occurs mainly via the release of uranyl species. Moreover, in contaminated soils from the sites of uranium mining, milling and enrichment, uranium is also found mainly in the uranyl form. The mobility of hydroxo and carbonato uranyl complexes in aqueous systems is a severe problem for many nuclear legacy sites. The mechanisms of uranyl retention via sorption, incorporation, precipitation, and reduction, among other processes, are being studied under simulated natural and waste disposal conditions. In addition to laboratory modeling, the most effective strategies for $\mathrm{U}$ immobilization are identified via field tests and case studies.

The remediation of contaminated soils faces the problem of selecting a technical strategy. This is complicated by the factors that affect the behavior of uranium, which include the soil type, the mineral composition, the natural organic matter (OM), and the initial forms of uranium; see, for example Selvakumar et al. (2018) and references therein. In the case of uranium contamination of the vadose zone, especially in arid and semiarid climates, there are two main ways to prevent uranium from entering groundwater in quantities that exceed acceptable levels: by monitoring natural attenuation (e.g., through adsorption processes or radioactive decay) or by remedial actions (e.g., mass or mobility reduction of uranium) (Dresel et al., 2011). The Hanford site's natural-technological system is one of the most studied in terms of uranium behavior in the interactions of acidic, neutral, and alkaline wastes with deposits (Szecsody et al., 2013; Gartman et al., 2015). At two contaminated sites, Hanford 300A (Columbia River) and Rifle (Colorado River), subsurface uranium plumes have been examined following the surface excavation of contaminated materials (Zachara et al., 2013). The rate of the observed uranium decrease was much lower than expected at both sites. The mechanisms that control the plume persistence were considered. At the Hanford 300A site, $\mathrm{U}(\mathrm{VI})$ that is sorbed in the vadose zone enters the oxidizing aquifer during spring water excursion, and uranium release into the groundwater is controlled by kinetically limited surface complexation. At the Rifle site, U(IV) is slowly oxidized in the suboxic groundwater. The additional influx of $\mathrm{U}(\mathrm{VI})$ from the upper vadose zone is also controlled by surface complexation; however, its contribution is local, and it is not the dominant 


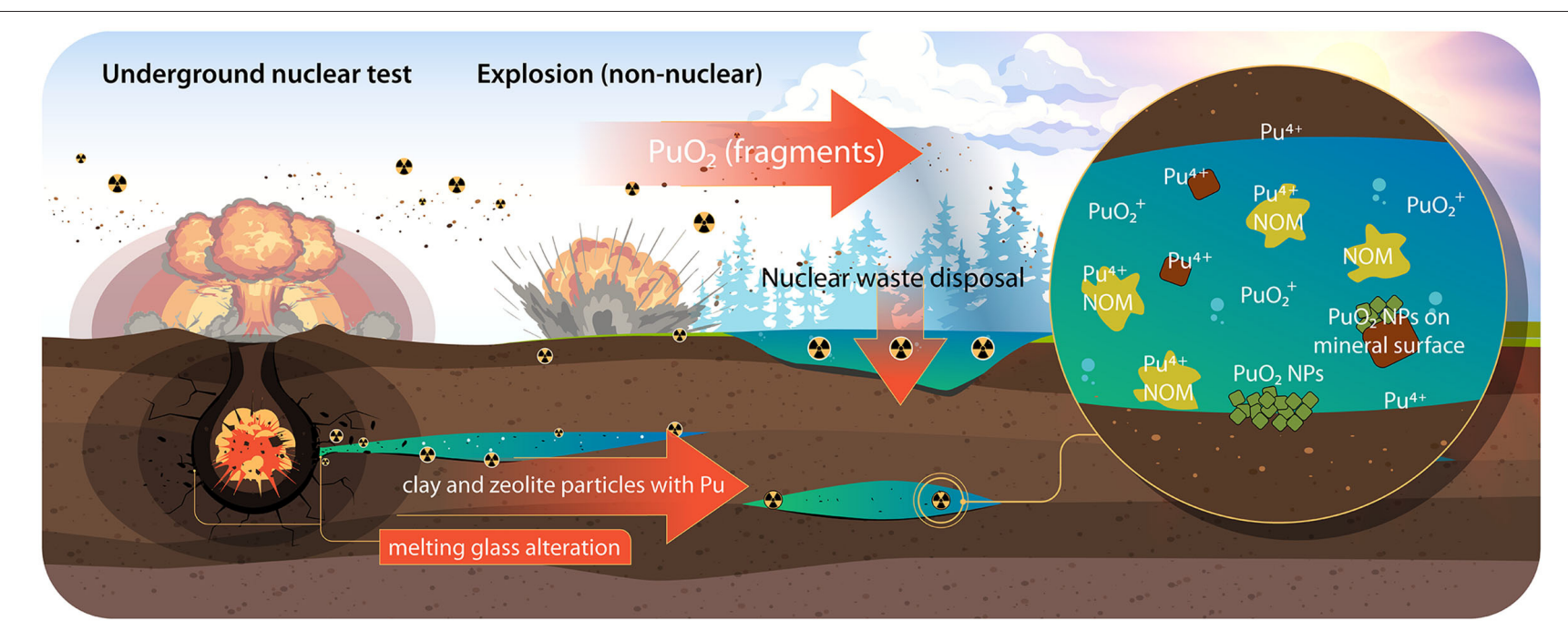

FIGURE 2 | Pu migration into the environment. NP, nanoparticle; NOM, natural organic matter.

mechanism of plume spreading. Thus, field studies show a wide variety of conditions and forms of uranium in real sites; hence, laboratory studies of the dependence of the uranium behavior on each of the environmental factors are required.

The behavior of uranyl in the presence of $\mathrm{Ca}^{2+}$ and $\mathrm{CO}_{3}^{2-}$ has been studied. At neutral $\mathrm{pH}$ and low concentrations $(<500 \mu \mathrm{M})$, $\mathrm{U}(\mathrm{VI})$ sorbs on the calcite surface with the formation of innersphere uranyl triscarbonate complexes, whereas at high $U$ concentrations, U(VI) forms hydroxide/carbonato precipitates (Elzinga et al., 2004). The incorporation of uranium into the calcite and vaterite structure at the $\mathrm{Ca}^{2+}$ sites with aging was demonstrated in the case of at least a decimolar Ca concentration (Kelly et al., 2003, 2006; Niu et al., 2019). Experimental modeling of geological disposals under hyperalkaline calcite conditions at high $\mathrm{U}$ concentrations [at least $4.2 \mu \mathrm{M} \mathrm{U}(\mathrm{VI})$ ] demonstrated the precipitation of calcium uranate-type phases (Mace et al., 2013; Smith et al., 2015). At low U(VI) concentrations, the formation of liebigite-like $\mathrm{Ca}_{2} \mathrm{UO}_{2}\left(\mathrm{CO}_{3}\right)_{3}$ surface complexes and binding to calcium silicate hydrates were confirmed. The difference in uranium behavior at low concentrations under neutral and high $\mathrm{pH}$ was observed; in the former case, the surface complexation dominates while, in the latter, uranium mainly precipitates (Smith et al., 2015). At the same time, it was demonstrated that $\mathrm{U}(\mathrm{VI})$ sorption on orthoclase and muscovite could be reduced by the presence of $\mathrm{Ca}^{2+}$ at a millimolar concentration at $\mathrm{pH}$ $>8$ by up to $30 \%$ due to the formation of the neutral aqueous $\mathrm{Ca}_{2} \mathrm{UO}_{2}\left(\mathrm{CO}_{3}\right)_{3}$ complex (Richter et al., 2016). The study of the ternary system of $\mathrm{Ca}^{2+}-\mathrm{U}(\mathrm{VI})-\mathrm{CO}_{3}^{2-}$ remains relevant because it covers diverse processes, such as the sorption, precipitation, and incorporation of uranium in the structure of calcium carbonate, which depend on the concentration of each member of the ternary system and the environment.

A study of the behavior of uranyl in the presence of clay minerals, one of the most common components of the environment, was conducted for $U$ mill and mine tailing material from Saskatchewan, Canada (Schindler et al., 2015). The absorption of uranyl in the alteration zones of clay minerals and intergrowth of silicates and uranyl minerals were demonstrated along with processes of the nucleation of nanocrystals of uranyl-arsenates and silicates: cuprosklodowskite, $\mathrm{Cu}\left[\left(\mathrm{UO}_{2}\right)_{2}\left(\mathrm{SiO}_{3} \mathrm{OH}\right)_{2}\right]\left(\mathrm{H}_{2} \mathrm{O}\right)_{6}$, and metazeunerite, $\mathrm{Cu}\left[\left(\mathrm{UO}_{2}\right)\left(\mathrm{AsO}_{4}\right)_{2}\right]\left(\mathrm{H}_{2} \mathrm{O}\right)_{8}$.

Iron oxides and oxyhydroxides appear to significantly change the behavior of uranium, and their effects continue to be studied as the new data raises new questions. Uranyl reduction to $\mathrm{U}(\mathrm{V})$ and incorporation into Fe(II/III) oxides and oxyhydroxides in cement leachates were studied under simulated geological disposal conditions at high pH (Marshall et al., 2014, 2015) and under neutral pH (Boland et al., 2014). The uranium sorption on ferrihydrite in the presence of natural organic matter (NOM) was investigated (Dublet et al., 2017), and it was shown that the effect on uranyl sorption depended on the $\mathrm{pH}$ and the type of NOM.

Research on uranium speciation at contaminated sites has been followed by work on the leaching, purification, and immobilization of uranium. Various approaches have been tested and revised, and recently, many laboratory studies and field tests have been conducted with the objective of evaluating the reliability of uranium retention.

There are two reliable mechanisms for the transformation of uranium from a mobile form to a solid phase in a field case: phosphate precipitation and reduction. Both are thoroughly investigated with site samples. The mobility of uranium, which is found in deposits as the relatively soluble carbonate and hydroxocomplexes, was found to be decreased by the introduction of polyphosphate solutions, thereby resulting in the precipitation of calcium uranyl phosphate (Mehta et al., 2016). Kanematsu et al. have studied uranium speciation in the solids that precipitated from synthetic acidic to neutral wastewaters in the presence and absence of dissolved silica and phosphate using $\mathrm{U}_{\mathrm{III}}$-edge EXAFS. It was revealed that rapidly 
precipitated autenite $\left[\mathrm{Ca}\left(\mathrm{UO}_{2}\right)_{2}\left(\mathrm{PO}_{4}\right)_{2} \cdot 10-12\left(\mathrm{H}_{2} \mathrm{O}\right)\right]$-type and meta-ankoleite $\left[\mathrm{K}_{2}\left(\mathrm{UO}_{2}\right)_{2}\left(\mathrm{PO}_{4}\right)_{2} \cdot 6 \mathrm{H}_{2} \mathrm{O}\right]$-type sheets transform into phosphuranylite $\left[\mathrm{K}_{2} \mathrm{Ca}\left(\mathrm{UO}_{2}\right)_{7}\left(\mathrm{PO}_{4}\right)_{4}(\mathrm{OH})_{6} \cdot 6 \mathrm{H}_{2} \mathrm{O}\right]$-type sheets after 30 days of reaction. This study proved that particle size, crystallinity, and composition of the precipitates control the thermodynamic and kinetic stability of uranyl solids in sediments that are impacted by acidic/neutral waste discharges (Kanematsu et al., 2014). The forms of uranium in a similar system, uranylsilica-phosphate, were studied by Perdrial et al. In a phosphatefree system, uranium speciation was controlled initially by the precipitation of compreignacite $\left[\mathrm{K}_{2}\left(\mathrm{UO}_{2}\right)_{6} \mathrm{O}_{4}(\mathrm{OH})_{6} \cdot 8 \mathrm{H}_{2} \mathrm{O}\right]$ and becquerelite $\left[\mathrm{Ca}\left(\mathrm{UO}_{2}\right)_{6} \mathrm{O}_{4}(\mathrm{OH})_{6} \cdot 8 \mathrm{H}_{2} \mathrm{O}\right]$-like species. The subsequent removal of uranium coincided with that of silicon and the accumulation of boltwoodite [(K, $\left.\mathrm{Na})\left(\mathrm{UO}_{2}\right)_{2} \mathrm{O}_{4}\left(\mathrm{HSiO}_{4}\right)_{2} \cdot 0.5\left(\mathrm{H}_{2} \mathrm{O}\right)\right]$-like species after 180 and 365 days. In the presence of $\mathrm{PO}_{4}^{3-}$, meta-ankoleite $\left[\mathrm{K}_{2}\left(\mathrm{UO}_{2}\right)_{2} \mathrm{O}_{4}\left(\mathrm{PO}_{4}\right)_{2} \cdot 6 \mathrm{H}_{2} \mathrm{O}\right]$-like species exerted direct and strong control over U speciation (Perdrial et al., 2018). The dynamics of the precipitation-sorption-phase evolution in the uranyl-phosphate system at a $\mathrm{pH}$ of 6 in a several-week experiment was studied in the presence of goethite and mica to simulate the environment (Munasinghe et al., 2015). Chernikovite $\left[\left(\mathrm{H}_{3} \mathrm{O}\right)_{2}\left(\mathrm{UO}_{2}\right)_{2}\left(\mathrm{PO}_{4}\right)_{2} \cdot 6\left(\mathrm{H}_{2} \mathrm{O}\right)\right]$ was the first rapidly precipitated form in the experiments with $\mathrm{U}$ and $\mathrm{P}$ while partially hydrated (meta)autenite was formed only in the presence of goethite. The transition between phases was accelerated by sorption.

The bioavailability of uranium at near-surface contaminated sites is determined by the phosphate forms of uranyl, which are easily taken up by the plants (Edayilam et al., 2020). The complexity of the uranyl-phosphate system and its practical significance, highlighted in this review, support the necessity of its further study.

Emerson et al. proved the retardation of uranium on treatment with bases, such as sodium hydroxide, ammonium hydroxide, and ammonia gas, in the presence of various minerals and natural sediments from the Hanford site (Washington State, USA) (Emerson et al., 2018). The control of the $\mathrm{pH}$ with ammonia gas injection may be especially useful for vadose zone environments as it does not require the addition of liquids that would increase the flux toward the groundwater. The authors suggest that the likely mechanisms for the transfer of uranium from the aqueous to the solid phase are the formation of surface coatings, coprecipitation with carbonates, and adsorption.

\section{Uranium and Organic Matter}

Luo and Xu (2016) proved the key role of thiol groups in NOM. They are responsible for the bioremediation and immobilization of uranium when it enters the environment (soil, groundwater). Bioreduction, followed by reoxidation by oxygen, can sequestrate $\mathrm{U}$ via the formation of stable U-coated particles, as was shown by Li et al. (2019). The dual effects of microorganisms on the behavior of uranium (reduction or rapid reoxidation), along with biosorption, bioaccumulation, and biomineralization, are reviewed in Cumberland et al. (2016). Uncertainties that are associated with the oxidation state and mobility of uranium, which is influenced by microorganisms, on both the geological and molecular scales are reviewed in this work. Available information on the uranium-OM bond and the solubility of U-OM was collected and analyzed. During the biosorption of uranium by fungal cells, the oxidation state of uranium was unchanged while the uranium speciation did change (Günther et al., 2014). Extra- and intracellular phosphate groups are mainly responsible for uranium binding.

The interaction between uranium and NOM is especially important in wetlands. There are many examples of wetlands in which this interaction governs the partitioning (Kaplan et al., 2016, 2017; Koster van Groos et al., 2016; Mikutta et al., 2016; Schumann et al., 2017; Dublet et al., 2019; Stetten et al., 2020). One of the main characteristics of these places is the significant seasonal change. During the hot season, the wetlands become dry, and the oxidative conditions occur, while during the floods or even frozen season, the reductive conditions may change the uranium speciation. Examples around the world show all of these processes: oxidation/reduction together with precipitation/dissolution and sorption/complexation. Future research in this area could identify the relationship between the seasonal changes and the various parameters, such as the temperature, $\mathrm{Eh}, \mathrm{pH},\left[\mathrm{PO}_{4}^{3+}\right],[\mathrm{NOM}]$, microbial and plant community and uranium behavior.

\section{Thermodynamic Modeling and Instrumental Techniques}

Both the prediction of the uranium distribution in the environment and the selection of an efficient remediation strategy require the use of thermodynamic constants for reactions that involve $\mathrm{U}$. The available databases for uranium (Grenthe et al., 1992; Guillaumont et al., 2003) lack many constants. In some cases, published constants differ significantly, and sometimes the data obtained are not in accordance with the current state of knowledge. The validation of available thermodynamic data and their refinement or the acquirement of new data are of substantial importance for investigating the behavior of uranium in nature. For example, thermodynamic data for the ternary complexation of calcium uranyl tricarbonate species $\mathrm{CaUO}_{2}\left(\mathrm{CO}_{3}\right)_{3}^{2-}$ and $\mathrm{Ca}_{2} \mathrm{UO}_{2}\left(\mathrm{CO}_{3}\right)_{3}(\mathrm{aq})$ in the temperature range of $10-70^{\circ} \mathrm{C}$ were obtained in Jo et al. (2019) using time-resolved laser-induced fluorescence spectroscopy (TRLFS), ion-selective electrode potentiometry, and UV/vis adsorption spectroscopy. Thermodynamic modeling of uranium species and its comparison with the experimental data that were obtained via direct non-destructive methods is necessary to investigate of uranium behavior at the contaminated sites. The use of different databases for the same water composition leads to substantial differences in modeling as was shown by Mühr-Ebert et al. (2019). To clarify this, the researchers optimized the thermodynamic data using model calculations and laboratory tests by TRLFS, mass spectrometry, and extraction experiments under various model conditions (Mühr-Ebert et al., 2019).

The recent rapid development of spectrometric, microscopic, and other analytical methods enables us to better understand the processes that occur at the contaminated sites. Nondestructive techniques, such as scanning electron microscopy 
(SEM) and transmission electron microscopy (TEM) with energy-dispersive X-ray analysis (EDX), are increasingly being used together with semidestructive secondary-ionization mass spectrometry (SIMS).

In addition to the classic methods, such as TRLFS, a highly sensitive method for the identification and detection of uranium species in solids and solutions is vibration spectroscopy, including infrared absorption and Raman scattering ( $\mathrm{Lu}$ et al., 2018). The main advantage of these techniques is the possibility of in situ detection and the real-time monitoring of chemical reactions that involve uranium.

A combination of experiments and calculations in the identification of uranium species yields acceptable results. For example, five uranyl aqueous complexes under a fixed $\mathrm{U}$ conc. $\left(10^{-5} \mathrm{M}\right)$ over a wide $\mathrm{pH}$ range from 2 to 11 were identified from the TRLFS data with parallel factor analysis, UV excitation spectra $(180-370 \mathrm{~nm})$ and time-dependent density functional theory. The combination of experiment and theory confirmed the presence of the $\left[\mathrm{UO}_{2}\left(\mathrm{H}_{2} \mathrm{O}\right)_{5}\right]^{2+}$ cation (aquo-complex 1:0) and the four hydroxo-complexes (1:1, 3:5, 3:7, and 1:3) (Drobot et al., 2015).

Synchrotron radiation X-ray techniques, such as X-ray fluorescence (XRF), diffraction (XRD), and absorption spectrometry (XAFS), especially with a submicron beam, provide information on the local molecular speciation (Kelly et al., 2006; Kanematsu et al., 2014; Smith et al., 2015). Recent study of the oxidation state of uranium and the structure of electronic orbitals using resonant inelastic X-ray scattering (RIXS) and HERFD-XANES measurements at the $\mathrm{U} \mathrm{L}_{\mathrm{III}}$ (Kvashnina et al., 2015), U M $\mathrm{IV}_{\mathrm{IV}}$ (Kvashnina et al., 2013; Butorin et al., 2016) and Pu edges (Vitova et al., 2017; Kvashnina et al., 2019) give promising results for future applications. However, a significant limitation of these experimental methods is that the uranium concentrations, even at highly contaminated sites, are often below the detection limits of advanced analytical methods. Therefore, indirect destructive methods, such as sequential extraction and solvent extraction, remain the only available methods to obtain the information.

Uranium-containing phases were identified using advanced techniques in sludges from Hanford tanks (Peterson et al., 2018). The uranium concentration in radioactive waste is much higher than in the environment of the LRW storage. A limitation of this experimental approach is that in model systems, the uranium concentrations are $10^{-5}-10^{-7} \mathrm{~mol} / \mathrm{L}$ while the uranium concentrations at contaminated sites are below the detection limits of advanced analytical methods. Even in studies in which XANES spectra for extremely low uranium concentrations were obtained (Zhang et al., 2016), the U content is about $40 \mathrm{ppm}$, which is not always the case for the contaminated soils. Few applications of advanced techniques for the identification of $U$ species in the environment are available (Tayal et al., 2019). This research should be continued, but destructive analyses will inevitably have to be used to identify uranium partitioning in mobile fractions as they are often the only methods for determining the forms of uranium; see Qiao et al. (2012) and Skipperud et al. (2013).

\section{Uranium in "Hot" Particles and Corium}

In the case of accidental fuel fallout, such as the Chernobyl fallout, uranium enters the environment initially as U(IV) species, mainly as uranium dioxide, which is partially oxidized, and sometimes as mixed uranium-zirconium dioxide $\left(\mathrm{UO}_{2+\mathrm{x}}\right.$, $(\mathrm{U}, \mathrm{Zr}) \mathrm{O}_{2}$ ) (Pöml and Burakov, 2018; Shiryaev et al., 2018) (Figure 1). The solubility of these fuel particles depends more on the conditions of their formation than on the environment (Kashparov et al., 2019). The most kinetically stable are those $(\mathrm{U}, \mathrm{Zr}) \mathrm{O}_{2}$ particles that were formed at the maximum temperature during an accident. $\mathrm{UO}_{2}$ particles are less stable than $(\mathrm{U}, \mathrm{Zr}) \mathrm{O}_{2}$ particles. The $\mathrm{UO}_{2+\mathrm{x}}$ particles are the most soluble and the least stable. In addition to uranium, fuel particles contain fission products and transuranium elements and their behavior is associated with the behavior of the particles. According to the similarity of the chemical behaviors of $\mathrm{Sr}, \mathrm{Cs}$, and $\mathrm{Am}$ in the Polesie soils, these radionuclides bind to fuel particles (Bondarkov et al., 2011). For more than 30 years since the Chernobyl accident, we have traced the kinetics of the dissolution/destruction of fuel particles based on a large amount of statistical data (Beresford et al., 2016; Lecomte-Pradines et al., 2020).

Uranium can enter the environment in the form of uranium dioxide particles during an accidental discharge, such as the pollution of the Yenisei River (Bolsunovsky et al., 2017), and via regular technological influxes of liquid RW into storage pools, in which liquid RW accumulates in the bottom sediments and into sludge storage pools (Batuk et al., 2015).

A special form of uranium is corium, the molten zone of an emergency reactor. The lava-like fuel-containing materials that formed in the 4th Chernobyl NPP unit have been studied for a long time, and recently, additional analytical methods have become available to study the forms of radionuclides, such as uranium (Shiryaev et al., 2016; Burakov, 2019). The obtained data on the structures and the phase compositions of lavalike materials will facilitate the prediction of the kinetics of the mechanical destruction of "lava" and the development of best strategies for handling this type of radioactive waste, which will also be useful for handling the corium of the Fukushima Daiichi emergency reactors. Numerous core melt model studies have been conducted, and sacrificial materials have been selected (Veshchunov et al., 2008; Knebel et al., 2017).

\section{PLUTONIUM}

Plutonium can exist in four oxidation states: $\mathrm{Pu}(\mathrm{III}), \mathrm{Pu}(\mathrm{IV})$, $\mathrm{Pu}(\mathrm{V})$, and $\mathrm{Pu}(\mathrm{VI})$. These states can even exist simultaneously under suitable environmental conditions. The redox potentials for switching between the oxidation states are close to $1 \mathrm{~V}$ for many reactions, which creates a unique scenario in which multiple oxidation states can coexist in solution (Clark et al., 2005). The oxidation state of plutonium controls its reactivity and solubility. $\mathrm{Pu}(\mathrm{VI})$ and $\mathrm{Pu}(\mathrm{V})$ are more soluble in water than $\mathrm{Pu}(\mathrm{IV})$ and $\mathrm{Pu}(\mathrm{III})$. The most important reactions for the environmental plutonium behavior are sorption, complexation, 
precipitation, and colloid formation, on all of which the oxidation state has the most profound influence.

Far fewer studies have been published on the behavior of plutonium than on that of uranium in the environment.

\section{Colloid Transport}

The $\mathrm{Pu}$ migration in the environment was investigated at the Nevada National Security Site (NNSS), where 828 underground nuclear tests were conducted, and $\mathrm{Pu}$ was found in two aquifers, $1.3 \mathrm{~km}$ away from a nuclear test location (Kersting et al., 1999). Over $95 \%$ of the $\mathrm{Pu}$ in the groundwater well was associated with colloidal particles (mainly clays and zeolites). In recent years, the mechanism of the formation of these $\mathrm{Pu}$ species has been deeply clarified. It was found that alteration of the NNSS nuclear melt glass under hydrothermal conditions that likely occurred in the vicinity and aftermath of the underground nuclear explosion resulted in the formation of mineral colloids, which are similar to those that were reported in 1999, and plutonium was predominantly associated with them (Zavarin et al., 2019) (Figure 2). It was concluded that colloid-bound $\mathrm{Pu}$ was produced as a result of nuclear melt glass aging, which suggests that the local geochemistry of the test site may not be very important in the first stages of the migration. The authors attempted to describe the subsequent leaching of plutonium from these colloids. The results suggest that the hydrothermal conditions during colloid formation affect the $\mathrm{Pu}$ desorption rates from the colloids (Joseph et al., 2019). The desorption rates of $\mathrm{Pu}$ from the colloids that were formed at $140^{\circ} \mathrm{C}$ can be modeled based on the kinetics of $\mathrm{Pu}$ sorption/desorption onto montmorillonite at room temperature. The authors estimate that the half-life of $\mathrm{Pu}$ on colloids is on the order of 0.6-1.8 years (Begg et al., 2017). The $\mathrm{Pu}$ that is bound to zeolite and clay colloids at higher temperatures $\left(\geq 200^{\circ} \mathrm{C}\right)$ is more stable, and the desorption rate of $\mathrm{Pu}$ from these colloids is at least one order of magnitude slower than that for the colloids formed by leaching at a lower temperature.

The study of the colloid transport of Pu from Lake Karachay (PA “Mayak," Russia) (Novikov et al., 2006) found that a significant fraction of the plutonium is bound to colloids with a size $<15 \mathrm{~nm}$ made of amorphous ferrihydrite. Many studies have been conducted on the sorption of plutonium onto mineral colloids to understand its transport. The plutonium sorption is complicated by redox reactions; hence, this topic remains open for discussion and study (Romanchuk et al., 2016b). Recently, it was found that $\mathrm{Pu}(\mathrm{IV})$ stabilization onto mineral surfaces may result in $\mathrm{Pu}$ surface precipitation in the form of $\mathrm{PuO}_{2}$ nanoparticles (Kirsch et al., 2011; Romanchuk et al., 2013, 2016a; Schmidt et al., 2013; Zhao et al., 2016) (Figure 2). Therefore, the study of $\mathrm{PuO}_{2}$ nanoparticles becomes increasingly important, and it is actively being conducted (Powell et al., 2011; Romanchuk et al., 2018; Kvashnina et al., 2019; Gerber et al., 2020).

The strong interaction of $\mathrm{Pu}$ with minerals and sediments results in stable association with no leaching is observed even after 32 years of aging (Emerson et al., 2019). In this study, solvent extraction of $\mathrm{Pu}$ that was bound with the surface for 3 days and for 32 years shows that the aging changes the speciation of $\mathrm{Pu}$ on the surface; however, the exact mechanism of the aging remains undefined. Understanding of the aging and of the stronger $\mathrm{Pu}$ binding with minerals or colloids is important for the prediction of $\mathrm{Pu}$ transport in the environment.

\section{Plutonium and NOM}

Most of the plutonium that was released into the environment during the Chernobyl accident was associated with uranium particles. The subsequent migration of this plutonium was controlled by the dissolution of these particles; see above. The plutonium concentration in the groundwater of the Chernobyl Exclusion Zone remains low (Bugai et al., 2020). However, these concentrations are much higher than those that are determined via simple calculations that apply the distribution coefficient $\left(K_{\mathrm{d}}\right)$ concept. A relatively low $K_{\mathrm{d}}$ of plutonium was obtained for the in situ experiments compared to the values that were reported for a batch. The mechanism of this overstated plutonium migration remains to be identified. It can most likely be explained by facilitated transport in the form of mobile colloids or of complexes with NOM, especially considering the local geochemistry. For example, (Levchuk et al., 2012) demonstrated using ultrafiltration that a large fraction of the plutonium in the groundwater of the "Red forest" $(5 \mathrm{~km}$ from the Chernobyl NPP) is bound with low-molecular-weight NOM $(<1$ $\mathrm{kDa}$ ) and humic and fulvic acids.

The influence of organic substances on plutonium migration has been discussed in other works (Zhao et al., 2011; Santschi et al., 2017; Lin et al., 2019). In the NNSS vadose zone, the water that was collected in a tunnel system had plutonium predominantly as an aqueous species, which was not bound with colloids (Zhao et al., 2011). It was found that more than $70 \%$ of the plutonium was complexed with dissolved organic matter and that its high content $(15-19 \mathrm{mg} / \mathrm{L})$ could be attributed to anthropogenic mining activity.

Another example of the influence of organic matter on the behavior of $\mathrm{Pu}$ was found in the Nishiyama reservoir (Nagasaki, Japan) (Lin et al., 2019). Nagasaki is the only city in the world where a $\mathrm{Pu}$ bomb was exploded. As a result, an area of $3-5 \mathrm{~km}^{2}$ in Nagasaki was highly contaminated by 200 radioactive isotopes. Plutonium precipitated to the earth as a "black rain," which is a mixture of soot carbon and water. High levels of plutonium remain in the sediments of the Nishiyama reservoir. Most of the $\mathrm{Pu}$ in the sediments was preferentially bound to the organic matter that was stabilized by Fe oxides. The authors conclude that the chelation of $\mathrm{Pu}$ by the hydroxamate siderophores occurs in the sub-/surface soils, similar to the F-area of the Savannah River site and the Fukushima prefecture (Santschi et al., 2017). Santschi et al. proposed that $\mathrm{Pu}(\mathrm{IV})$ may become even more mobile than oxidized $\mathrm{Pu}(\mathrm{V} / \mathrm{VI})$. As a result, $\mathrm{Pu}(\mathrm{IV})$ bound with organic matter can form mobile colloids, especially at higher $\mathrm{pH}$. Therefore, NOM can immobilize or remobilize $\mathrm{Pu}$ depending on the $\mathrm{pH}$. This effect should be considered in the migration modeling and should be studied further. The data on the influence of NOM on the interaction of $\mathrm{Pu}$ with minerals and sediments are limited. 


\section{Pu in "Hot" Particles}

Synchrotron-based techniques, especially with microresolution, may help in the speciation of $\mathrm{Pu}$-containing particles. A valuable example is the remediation of the Rocky Flats environmental technology site. A combination of XANES and EXAFS methods facilitated the detection of $\mathrm{PuO}_{2}$-like particles in the soil (Conradson et al., 2011). These particles exhibit slow leaching with no production of secondary forms of plutonium. Thus, the remediation process could be made cheaper and easier.

Another example is a study of Pu-containing particles at the Taranaki site, which is in southern Australia, where 500 nonnuclear explosions were conducted in 1953-1963 (Ikeda-Ohno et al., 2016). Applying modern $\mu$-XRF and $\mu$-XANES techniques, the authors determined that the initial detonation of the weapon components resulted in the formation of $\mathrm{PuO}_{2}$ particles that contain $\mathrm{Pb}$. However, storage in the soil and the environmental reactions result in the precipitation or sorption on the surface of $\mathrm{Pu}$ particles. A core-shell structure with a $\mathrm{Ca} / \mathrm{Fe} / \mathrm{U}$ shell and a $\mathrm{PuO}_{2}$ core were identified by the authors. These particles can be compared with the particles formed in the accidents in Palomeras (Spain) and Thule (Greenland). In each case, the accident occurred with a B-52 bomber. In Palomeras, a non-nuclear explosion of two weapons with subsequent fire resulted in the dispersion of $\mathrm{Pu}-\mathrm{U}$ particles over a $2.30 \mathrm{~km}^{2}$ area. In the Thule accident, a bomber crashed on the ice in the North Star Bay, $12 \mathrm{~km}$ west of Thule Air Base, due to a flight mission accident. This non-nuclear explosion also resulted in the dispersion of $\mathrm{Pu}-\mathrm{U}$ particles in marine and terrestrial environments. The composition and properties of the particles in both accidents are similar (Lind et al., 2007). U and Pu oxide mixtures constitute the cores of the particles. The authors found that the oxidation state of $\mathrm{U}$ is predominately $\mathrm{U}(\mathrm{IV})$ with minor contributions from higher oxidation states (up to $\mathrm{U}_{3} \mathrm{O}_{8}$ ). Characterization of $\mathrm{Pu}$ shows it to be $\mathrm{Pu}(\mathrm{III}) / \mathrm{Pu}(\mathrm{IV}), \mathrm{Pu}(\mathrm{IV}) / \mathrm{Pu}(\mathrm{V})$, or a mixture of all three oxidation states. The particles in both accidents appear to be similar; however, their storage conditions differ. In the Thule accident, most of the particles were aged in a marine environment while a small fraction was aged in a terrestrial ecosystem that remains frozen for most of the year. In the Palomares accident, a terrestrial semi-desert ecosystem was mainly affected (Sancho and García-Tenorio, 2019). According to the leaching experiments (by $0.16 \mathrm{M} \mathrm{HCl}$ ) of the EU-COMET project, the "hot" particles from the Thule sediment are more leachable than those from the Palomares soils (Vandenhove et al., 2017). These data demonstrate that the weathering of "hot" particles and their evolution over time may depend not only on the contamination scenario, but also on the storage conditions.

\section{$\mathrm{Pu}$ in Waste Storage}

A more complicated scenario is found in the radioactive waste disposal sites and in the pathways of migration from them. Many studies have been conducted on the temporary storage or disposal of liquid and solid radioactive wastes. The composition of the radioactive waste and the environmental conditions of disposal differ substantially from one disposal to another. Unfortunately, only a few of them are open for scientific discussion.
Recently, the migration of radionuclides from a legacy trench disposal site in eastern Australia was investigated (Payne et al., 2020). The authors studied the migration of actinides and fission products. It was found that mobilization of $\mathrm{Pu}$ from the trenches is related to complex interactions between the influx of oxidizing groundwater during rainfall and the subsequent extended period of reducing conditions. The microbial activity influences the distributions of actinides and other redox-sensitive elements, such as iron and manganese (Vázquez-Campos et al., 2017). The study shows seasonal changes in redox conditions, which can significantly change the migration of redox-sensitive actinides, especially $\mathrm{Pu}$. The differences in seasonal changes in properties, such as the temperature and rainfall throughout the world may significantly affect the redox-sensitive migration of radionuclides.

The microbiological community, which plays a special role in these biogeochemical processes, should also be considered. The influence of the microbiological activity of radionuclide migration in groundwater was demonstrated (Kersting, 2013; Kato et al., 2020). The authors agree that the interaction of $\mathrm{Pu}$ with microorganisms results in a reduction, but other processes may also be involved, such as sorption onto cell surface, accumulation within the cells, biomineralization and complexation. The exact mechanism of the interaction and its influence on the Pu mobility is not clear. The interaction of $\mathrm{Pu}(\mathrm{V})$ and $\mathrm{Pu}(\mathrm{IV})$ with cells in the presence and absence of extracellular polymeric substances (EPS) was investigated (Boggs et al., 2016). It was found that the reduction of $\mathrm{Pu}(\mathrm{V})$ mostly occur in the interaction with EPS. In all studied systems, by the end of the reaction, the cells immobilize $\mathrm{Pu}$ on their surface. However, in other works, the reduction of $\mathrm{Pu}(\mathrm{IV})$ to $\mathrm{Pu}(\mathrm{III})$ on reaction with cells increased the mobility of the radionuclides (Xie et al., 2018).

\section{OUTLOOK}

The behavior of plutonium and uranium in the environment strongly depends on their source and the local geochemical conditions. In this mini review, we highlighted recent studies of the migration pathways of these radionuclides.

The research could be continued in two ways. First, the experiments under controlled laboratory conditions, which are supported by instrumental methods and calculations, may facilitate the identification of the mechanism of the reaction on the molecular level. This information is highly necessary. Thermodynamic modeling should accompany these experiments because reliable prediction of behavior of radionuclides in the environment remains impeded. In addition, long-term laboratory experiments should be conducted because aging often changes the pathways of these reactions.

Second is the characterization of environmental and the onsite experiments. Modern advanced techniques enable us to understand the chemistry of the migration at the molecular level even at the contaminated sites. However, in most cases, these methods are limited by the sensitivity. The differences between the contaminated sites means that more research should be conducted. This may facilitate the development of an 
economical, environmentally friendly, and sustainable solution of the remediation process.

\section{AUTHOR CONTRIBUTIONS}

$\mathrm{AR}$ and IV designed and wrote the review with input from SK regarding the conception and editing of the manuscript.

\section{REFERENCES}

Arnold, P. L., Love, J. B., and Patel, D. (2009). Pentavalent uranyl complexes. Coord. Chem. Rev. 253, 1973-1978. doi: 10.1016/j.ccr.2009.03.014

Batuk, O. N., Conradson, S. D., Aleksandrova, O. N., Boukhalfa, H., Burakov, B. E., Clark, D. L., et al. (2015). Multiscale speciation of U and Pu at Chernobyl, Hanford, Los Alamos, McGuire AFB, Mayak, and Rocky Flats. Environ. Sci. Technol. 49, 6474-6484. doi: 10.1021/es506145b

Begg, J. D., Zavarin, M., and Kersting, A. B. (2017). Desorption of plutonium from montmorillonite: an experimental and modeling study. Geochim. Cosmochim. Acta 197, 278-293. doi: 10.1016/j.gca.2016.10.006

Beresford, N. A., Fesenko, S., Konoplev, A., Skuterud, L., Smith, J. T., and Voigt, G. (2016). Thirty years after the Chernobyl accident: what lessons have we learnt? J. Environ. Radioact. 157, 77-89. doi: 10.1016/j.jenvrad.2016.02.003

Boggs, M. A., Jiao, Y., Dai, Z., Zavarin, M., and Kersting, A. B. (2016). Interactions of plutonium with Pseudomonas sp. strain EPS-1W and its extracellular polymeric substances. Appl. Environ. Microbiol. 82, 7093-7101. doi: 10.1128/AEM.02572-16

Boland, D. D., Collins, R. N., Glover, C. J., Payne, T. E., and Waite, T. D. (2014). Reduction of U(VI) by Fe(II) during the Fe(II)-accelerated transformation of ferrihydrite. Environ. Sci. Technol. 48, 9086-9093. doi: 10.1021/es501750z

Bolsunovsky, A., Melgunov, M., Chuguevskii, A., Lind, O. C., and Salbu, B. (2017). Unique diversity of radioactive particles found in the Yenisei River floodplain. Sci. Rep. 7, 1-10. doi: 10.1038/s41598-017-11557-7

Bondarkov, M. D., Zheltonozhsky, V. A., Zheltonozhskaya, M. V., Kulich, N. V., Maksimenko, A. M., Farfán, E. B., et al. (2011). Assessment of the radionuclide composition of "hot Particles" sampled in the Chernobyl Nuclear Power Plant fourth reactor unit. Health Phys. 101, 368-374. doi: 10.1097/HP.0b013e31820dbc53

Bugai, D., Smith, J., and Hoque, M. A. (2020). Solid-liquid distribution coefficients (Kd-s) of geological deposits at the Chernobyl Nuclear Power Plant site with respect to $\mathrm{Sr}, \mathrm{Cs}$ and $\mathrm{Pu}$ radionuclides: a short review. Chemosphere 242, 125175. doi: 10.1016/j.chemosphere.2019.125175

Burakov, B. E. (2019). "Lava-like materials formed and solidified during chernobyl accident," in Comprehensive Nuclear Materials, ed R. Konings (Amsterdam: Elsevier), 1-15. doi: 10.1016/B978-0-12-803581-8.11686-8

Butorin, S. M., Modin, A., Vegelius, J. R., Kvashnina, K. O., and Shuh, D. K. (2016). Probing chemical bonding in uranium dioxide by means of highresolution X-ray absorption spectroscopy. J. Phys. Chem. C 120, 29397-29404. doi: 10.1021/acs.jpcc.6b09335

Clark, D. L., Hecker, S. S., Jarvinen, G. D., and Neu, M. P. (2005). "Plutonium," in The Chemistry of the Actinide and Transactinide Elements, eds L. R. Morss, N. M. Edelstein, J. Fuger (Dordrecht: Springer), 813-1264. doi: 10.1007/1-4020-3598-5_7

Conradson, S. D., Clark, D. L., Den Auwer, C., and Lezama-Pacheco, J. S. (2011). "X-ray absorption spectroscopy of plutonium particles at the Rocky Flats US Nuclear Weapons Production Site," in Actinide Nanoparticle Research, eds S. N. Kalmykov, and M. A. Denecke (Berlin: Springer-Verlag), 377-398. doi: 10.1007/978-3-642-11432-8_14

Cumberland, S. A., Douglas, G., Grice, K., and Moreau, J. W. (2016). Uranium mobility in organic matter-rich sediments: a review of geological and geochemical processes. Earth-Sci. Rev. 159, 160-185. doi: 10.1016/j.earscirev.2016.05.010

Dresel, P. E., Wellman, D. M., Cantrell, K. J., and Truex, M. J. (2011). Review: technical and policy challenges in deep vadose zone remediation of metals and radionuclides. Environ. Sci. Technol. 45, 4207-4216. doi: 10.1021/es101211t
All authors contributed to the article and approved the submitted version.

\section{FUNDING}

This work was supported by the Russian Science Foundation (Grant 19-73-20051).
Drobot, B., Steudtner, R., Raff, J., Geipel, G., Brendler, V., and Tsushima, S. (2015). Combining luminescence spectroscopy, parallel factor analysis and quantum chemistry to reveal metal speciation-a case study of uranyl(VI) hydrolysis. Chem. Sci. 6, 964-972. doi: 10.1039/C4SC02022G

Dublet, G., Lezama Pacheco, J., Bargar, J. R., Fendorf, S., Kumar, N., Lowry, G. V., et al. (2017). Partitioning of uranyl between ferrihydrite and humic substances at acidic and circum-neutral pH. Geochim. Cosmochim. Acta 215, 122-140. doi: 10.1016/j.gca.2017.07.013

Dublet, G., Worms, I., Frutschi, M., Brown, A., Zund, G., Bartova, B., et al. (2019). Colloidal size and redox state of uranium species in the porewater of a pristine mountain wetland. Environ. Sci. Technol. 53, 9361-9369. doi: 10.1021/acs.est.9b01417

Edayilam, N., Ferguson, B., Montgomery, D., Al Mamun, A., Martinez, N., Powell, B. A., et al. (2020). Dissolution and vertical transport of uranium from stable mineral forms by plants as influenced by the Co-occurrence of uranium with phosphorus. Environ. Sci. Technol. 54, 6602-6609. doi: 10.1021/acs.est.9b06559

Elzinga, E. J., Tait, C. D., Reeder, R. J., Rector, K. D., Donohoe, R. J., and Morris, D. E. (2004). Spectroscopic investigation of U(VI) sorption at the calcitewater interface. Geochim. Cosmochim. Acta 68, 2437. doi: 10.1016/j.gca.2003. 09.023

Emerson, H. P., Di Pietro, S., Katsenovich, Y., and Szecsody, J. (2018). Potential for $U$ sequestration with select minerals and sediments via base treatment. J. Environ. Manag. 223, 108-114. doi: 10.1016/j.jenvman.2018.06.012

Emerson, H. P., Kaplan, D. I., and Powell, B. A. (2019). Plutonium binding affinity to sediments increases with contact time. Chem. Geol. 505, 100-107. doi: 10.1016/j.chemgeo.2018.11.009

Gartman, B. N., Qafoku, N. P., Szecsody, J. E., Kukkadapu, R. K., Wang, Z., Wellman, D. M., et al. (2015). Uranium fate in Hanford sediment altered by simulated acid waste solutions. Appl. Geochem. 63, 1-9. doi: 10.1016/j.apgeochem.2015.07.010

Gerber, E., Romanchuk, A., Pidchenko, I., Amidani, L., Rossberg, A., Hennig, C., et al. (2020). The missing pieces of the $\mathrm{PuO}_{2}$ nanoparticles puzzle. Nanoscale. doi: 10.1039/D0NR03767B. [Epub ahead of print].

Grenthe, I., Fuger, J., Konnings, R., Lemire, R. J., Muller, A., Nguyen-Trung Cregu, C., et al. (1992). "Chemical thermodynamics of uranium," in Chemical Thermodynamics of Uranium, eds. H. Wanner and I. Forest (Paris: OECD Nuclear Energy Agency).

Guillaumont, R., Fanghanel, T., Neck, V., Fuger, J., Palmer, D. A., Grenthe, I., et al. (2003). Update on the Chemical Thermodynamics of Uranium, Neptunium, Plutonium, Americium and Technecium. Amsterdam: OECD Nuclear Energy Agency.

Günther, A., Raff, J., Merroun, M. L., Roßberg, A., Kothe, E., and Bernhard, G. (2014). Interaction of $\mathrm{U}(\mathrm{VI})$ with Schizophyllum commune studied by microscopic and spectroscopic methods. BioMetals 27, 775-785. doi: 10.1007/s10534-014-9772-1

Ikeda-Ohno, A., Shahin, L. M., Howard, D. L., Collins, R. N., Payne, T. E., and Johansen, M. P. (2016). Fate of plutonium at a former nuclear testing site in Australia. Environ. Sci. Technol. 50, 9098-9104. doi: 10.1021/acs.est.6b01864

Jo, Y., Kirishima, A., Kimuro, S., Kim, H. K., and Yun, J II. (2019). Formation of $\mathrm{CaUO}_{2}\left(\mathrm{CO}_{3}\right) 32$ - and $\mathrm{Ca}_{2} \mathrm{UO}_{2}\left(\mathrm{CO}_{3}\right)_{3}(\mathrm{aq})$ complexes at variable temperatures $\left(10-70^{\circ} \mathrm{C}\right)$. Dalt. Trans. 48, 6942-6950. doi: 10.1039/C9DT0 $1174 \mathrm{~A}$

Joseph, C., Balboni, E., Baumer, T., Treinen, K., Kersting, A. B., and Zavarin, M. (2019). Plutonium desorption from nuclear melt glass-derived colloids and implications for migration at the Nevada National Security Site, USA. Environ. Sci. Technol. 53, 12238-12246. doi: 10.1021/acs.est.9b03956 
Kanematsu, M., Perdrial, N., Um, W., Chorover, J., and O'Day, P. A. (2014). Influence of phosphate and silica on $\mathrm{U}(\mathrm{VI})$ precipitation from acidic and neutralized wastewaters. Environ. Sci. Technol. 48, 6097-6106. doi: $10.1021 /$ es4056559

Kaplan, D. I., Buettner, S. W., Li, D., Huang, S., Koster, P. G., Groos, V., et al. (2017). In situ porewater uranium concentrations in a contaminated wetland: effect of seasons and sediment depth. Appl. Geochem. 85, 128-136. doi: 10.1016/j.apgeochem.2016.11.017

Kaplan, D. I., Kukkadapu, R., Seaman, J. C., Arey, B. W., Dohnalkova, A. C., Buettner, S., et al. (2016). Iron mineralogy and uranium-binding environment in the rhizosphere of a wetland soil. Sci. Total Environ. 569, 53-64. doi: 10.1016/j.scitotenv.2016.06.120

Kashparov, V., Salbu, B., Levchuk, S., Protsak, V., Maloshtan, I., Simonucci, C., et al. (2019). Environmental behaviour of radioactive particles from chernobyl. J. Environ. Radioact. 208:106025. doi: 10.1016/j.jenvrad.2019.106025

Kato, K., Nagaosa, K., Kinoshita, T., Kastsuyama, C., Nazina, T., Ohnuki, T., et al. (2020). "Microbial ecological function in migration of radionuclides in groundwater," in Behavior of Radionuclides in the Environment I, eds K. Kato, A. Konoplev, and S. Kalmykov (Singapore: Springer), 1-35. doi: 10.1007/978-981-15-0679-6

Kelly, S. D., Newville, M. G., Cheng, L., Kemner, K. M., Sutton, S. R., Fenter, P., et al. (2003). Uranyl incorporation in natural calcite. Environ. Sci. Technol. 37, 1284-1287. doi: 10.1021/es025962f

Kelly, S. D., Rasbury, E. T., Chattopadhyay, S., Kropf, A. J., and Kemner, K. M. (2006). Evidence of a stable uranyl site in ancient organic-rich calcite. Environ. Sci. Technol. 40, 2262-2268. doi: 10.1021/es051970v

Kersting, A. B. (2013). Plutonium transport in the environment. Inorg. Chem. 52, 3533-3546. doi: 10.1021/ic3018908

Kersting, A. B., Efurd, D. W., Finnegan, D. L., Rokop, D. L., Smith, D. K., and Thompson, J. L. (1999). Migration of plutonium in groundwater at the Nevada Test Site. Nature 397, 56-59. doi: 10.1038/16231

Kirsch, R., Fellhauer, D., Altmaier, M., Neck, V., Rossberg, A., Fanghanel, T., et al. (2011). Oxidation state and local structure of plutonium reacted with magnetite, mackinawite, and chukanovite. Environ. Sci. Technol. 45, 7267-7274. doi: 10.1021/es200645a

Knebel, K., Bottomley, P. D. W., Rondinella, V. V., Lähde, A., and Jokiniemi, J. (2017). Characterisation of aerosols produced in a simulated severe nuclear accident using electron microscopy. J. Aerosol Sci. 106, 68-82. doi: 10.1016/j.jaerosci.2017.01.008

Koster van Groos, P. G., Kaplan, D. I., Chang, H., Seaman, J. C., Li, D., Peacock, A. D., et al. (2016). Chemosphere Uranium fate in wetland mesocosms: effects of plants at two iron loadings with different $\mathrm{pH}$ values. Chemosphere 163, 116-124. doi: 10.1016/j.chemosphere.2016.08.012

Kvashnina, K., Romanchuk, A., Pidchenko, I., Gerber, E., Trigub, A., Rossberg, A., et al. (2019). A novel meta-stable pentavalent plutonium solid phase on the pathway from aqueous $\mathrm{Pu}(\mathrm{VI})$ to $\mathrm{PuO}_{2}$ nanoparticles. Angew. Chem. Int. Ed. 58, 17558-17562. doi: 10.1002/anie.201911637

Kvashnina, K. O., Butorin, S. M., Martin, P., and Glatzel, P. (2013). Chemical state of complex uranium oxides. Phys. Rev. Lett. 111, 1-5. doi: 10.1103/PhysRevLett.111.253002

Kvashnina, K. O., Kvashnin, Y. O., Vegelius, J. R., Bosak, A., Martin, P. M., and Butorin, S. M. (2015). Sensitivity to actinide doping of uranium compounds by resonant inelastic X-ray scattering at uranium L3 edge. Anal. Chem. 87, 8772-8780. doi: 10.1021/acs.analchem.5b01699

Lecomte-Pradines, C., Adam-Guillermin, C., Gashchak, S., Bradshaw, C., Copplestone, D., and Beresford, N. A. (2020). More than thirty years after the Chernobyl accident: what do we know about the effects of radiation on the environment? J. Environ. Radioact. 211, 2019-2021. doi: 10.1016/j.jenvrad.2019.106108

Levchuk, S., Kashparov, V., Maloshtan, I., Yoschenko, V., and Van Meir, N. (2012). Migration of transuranic elements in groundwater from the near-surface radioactive waste site. Appl. Geochem. 27, 1339-1347. doi: 10.1016/j.apgeochem.2012.01.002

Li, P. S., Wu, W. M., Phillips, D. H., Watson, D. B., Kelly, S., Li, B., et al. (2019). Uranium sequestration in sediment at an iron-rich contaminated site at Oak Ridge, Tennessee via. bioreduction followed by reoxidation. J. Environ. Sci. China 85, 156-167. doi: 10.1016/j.jes.2019.05.028
Lin, P., Xu, C., Kaplan, D. I., Chen, H., Yeager, C. M., Xing, W., et al. (2019). Nagasaki sediments reveal that long-term fate of plutonium is controlled by select organic matter moieties. Sci. Total Environ. 678, 409-418. doi: 10.1016/j.scitotenv.2019.04.375

Lind, O. C., Salbu, B., Janssens, K., Proost, K., García-León, M., and GarcíaTenorio, R. (2007). Characterization of U/Pu particles originating from the nuclear weapon accidents at Palomares, Spain, 1966 and Thule, Greenland, 1968. Sci. Total Environ. 376, 294-305. doi: 10.1016/j.scitotenv.2006.11.050

Lu, G., Haes, A. J., and Forbes, T. Z. (2018). Detection and identification of solids, surfaces, and solutions of uranium using vibrational spectroscopy. Coord. Chem. Rev. 374, 314-344. doi: 10.1016/j.ccr.2018.07.010

Luo, H. W., and Xu, F. (2016). Bioreduction and reoxidation of uranium enhanced by thiol functional groups in natural organic matter. Chemosphere 147, 20-24. doi: 10.1016/j.chemosphere.2015.12.092

Mace, N., Wieland, E., Dahn, R., Tits, J., and Sceinost, A. C. (2013). EXAFS investigation on $\mathrm{U}(\mathrm{VI})$ immobilization in hardened cement paste: influence of experimental conditions on speciation. Radiochim. Acta 101, 379-389. doi: $10.1524 /$ ract.2013.2024

Marshall, T. A., Morris, K., Law, G., Mosselmans, W., Bots, P., Rberts, H., et al. (2015). Uranium fate during crystallization of magnetite from ferrihydrite in conditions relevant to the disposal of radioactive waste. Miner. Mag. 79, 1265-1274. doi: 10.1180/minmag.2015.079.6.02

Marshall, T. A., Morris, K., Law, G. T. W., Livens, F. R., Mosselmans, J. F. W., Bots, P., et al. (2014). Incorporation of uranium into hematite during crystallization from ferrihydrite. Environ. Sci. Technol. 48, 3724-3731. doi: 10.1021/es500212a

Mehta, V. S., Maillot, F., Wang, Z., Catalano, J. G., and Giammar, D. E. (2016). Effect of reaction pathway on the extent and mechanism of uranium(VI) immobilization with calcium and phosphate. Environ. Sci. Technol. 50, 3128-3136. doi: 10.1021/acs.est.5b06212

Mikutta, C., Langner, P., Bargar, J. R., and Kretzschmar, R. (2016). Tetra- and hexavalent uranium forms bidentate-mononuclear complexes with particulate organic matter in a naturally uranium-enriched Peatland. Environ. Sci. Technol. 50, 10465-10475. doi: 10.1021/acs.est.6b03688

Mühr-Ebert, E. L., Wagner, F., and Walther, C. (2019). Speciation of uranium: compilation of a thermodynamic database and its experimental evaluation using different analytical techniques. Appl. Geochem. 100, 213-222. doi: 10.1016/j.apgeochem.2018.10.006

Munasinghe, P. S., Elwood, M. E., Brooks, S. C., and Elwood, A. S. (2015). Dynamic interplay between uranyl phosphate precipitation, sorption, and phase evolution. Appl. Geochem. 58, 147-160. doi: 10.1016/j.apgeochem.2015.04.008

Niu, Z., Wei, X., Qiang, S., Wu, H., Pan, D., Wu, W., et al. (2019). Spectroscopic studies on $\mathrm{U}(\mathrm{VI})$ incorporation into $\mathrm{CaCO}_{3}$ : effects of aging time and U(VI) concentration. Chemosphere 220, 1100-1107. doi: 10.1016/j.chemosphere.2019.01.010

Novikov, A. P., Kalmykov, S. N., Utsunomiya, S., Ewing, R. C., Horreard, F., Merkulov, A., et al. (2006). Colloid transport of plutonium in the farfield of the Mayak Production Association, Russia. Science. 314, 638-641. doi: 10.1126/science.1131307

Payne, T. E., Harrison, J. J., Cendon, D. I., Comarmond, M. J., Hankin, S., Hughes, C. E., et al. (2020). Radionuclide distributions and migration pathways at a legacy trench disposal site. J. Environ. Radioact. 211, 106081. doi: 10.1016/j.jenvrad.2019.106081

Perdrial, N., Vázquez-Ortega, A., Wang, G., Kanematsu, M., Mueller, K. T., Um, W., et al. (2018). Uranium speciation in acid waste-weathered sediments: the role of aging and phosphate amendments. Appl. Geochem. 89, 109-120. doi: 10.1016/j.apgeochem.2017.12.001

Peterson, R. A., Buck, E. C., Chun, J., Daniel, R. C., Herting, D. L., Ilton, E. S., et al. (2018). Review of the scientific understanding of radioactive waste at the U.S. DOE Hanford Site. Environ. Sci. Technol. 52, 381-396. doi: 10.1021/acs.est.7b04077

Pidchenko, I., Kvashnina, K. O., Yokosawa, T., Finck, N., Bahl, S., Schild, D. et al. (2017). Uranium redox transformations after U(VI) coprecipitation with magnetite nanoparticles. Environ. Sci. Technol. 51, 2217-2225. doi: 10.1021/acs.est.6b04035

Pöml, P., and Burakov, B. (2018). Study of the redistribution of U, Zr, Nb, Tc, Mo, Ru, Fe, Cr, and $\mathrm{Ni}$ between oxide and metallic phases in the matrix of a multiphase chernobyl hot-particle extracted from a soil sample 
of the Western Plume. Radiochim. Acta 106, 985-990. doi: 10.1515/ract2018-2957

Powell, B. A., Dai, Z., Zavarin, M., Zhao, P., and Kersting, A. B. (2011). Stabilization of plutonium nano-colloids by epitaxial distortion on mineral surfaces. Environ. Sci. Technol. 45, 2698-2703. doi: 10.1021/es1033487

Qiao, J., Hansen, V., Hou, X., Aldahan, A., and Possnert, G. (2012). Speciation analysis of 129I, 137Cs, 232Th, 238U, 239Pu and $240 \mathrm{Pu}$ in environmental soil and sediment. Appl. Radiat. Isot. 70, 1698-1708. doi: 10.1016/j.apradiso.2012.04.006

Richter, C., Müller, K., Drobot, B., Steudtner, R., Großmann, K., Stockmann, M., et al. (2016). Macroscopic and spectroscopic characterization of uranium(VI) sorption onto orthoclase and muscovite and the influence of competing Ca2+. Geochim. Cosmochim. Acta 189, 143-157. doi: 10.1016/j.gca.2016.05.045

Roberts, H. E., Morris, K., Law, G. T. W., Mosselmans, J. F. W., Bots, P., Kvashnina, K., et al. (2017). Uranium(V) incorporation mechanisms and stability in $\mathrm{Fe}(\mathrm{II}) / \mathrm{Fe}(\mathrm{III})$ (oxyhydr)oxides. Environ. Sci. Technol. Lett. 4, 421-426. doi: 10.1021/acs.estlett.7b00348

Romanchuk, A. Y., Kalmykov, S. N., Egorov, A. V., Zubavichus, Y. V., Shiryaev, A. A., Batuk, O. N., et al. (2013). Formation of crystalline $\mathrm{PuO}_{2+\mathrm{x}}{ }_{n} \mathrm{H}_{2} \mathrm{O}$ nanoparticles upon sorption of $\mathrm{Pu}(\mathrm{V}, \mathrm{VI})$ onto hematite. Geochim. Cosmochim. Acta 121, 29-40. doi: 10.1016/j.gca.2013.07.016

Romanchuk, A. Yu., Kalmykov, S. N., Egorov, A. V., Zubavichus, Y. V., Shiryaev, A. A., Smirnov, E. A., et al. (2016a). Photoreduction of $\mathrm{Pu}(\mathrm{V}, \mathrm{VI})$ by $\mathrm{TiO}_{2}$. Radiochim. Acta 104, 843-851. doi: 10.1515/ract-2015-2494

Romanchuk, A. Y., Kalmykov, S. N., Kersting, A. B., and Zavarin, M. (2016b). Behaviour of plutonium in the environment. Russ. Chem. Rev. 85:995. doi: 10.1070/RCR4602

Romanchuk, A. Y., Plakhova, T. V., Egorov, A. V., Egorova, T. B., Dorovatovskii, P. V., and Zubavichus, Y. V. (2018). Redox-mediated formation of plutonium oxide nanoparticles. Dalt. Trans. 47, 11239-11244. doi: 10.1039/C8DT02396D

Rybalchenko, A. I., Pimenov, M. K., Kurochkin, V. M., Kamnev, E. N., Korotkevich, V. M., Zubkov, A. A., et al. (2005). Deep injection disposal of liquid radioactive waste in Russia, 1963-2002: results and consequences. Dev. Water Sci. 52, 13-19. doi: 10.1016/S0167-5648(05)52002-1

Sancho, C., and García-Tenorio, R. (2019). Radiological evaluation of the transuranic remaining contamination in Palomares (Spain): a historical review. J. Environ. Radioact. 203, 55-70. doi: 10.1016/j.jenvrad.2019.02.015

Santschi, P. H., Xu, C., Zhang, S., Schwehr, K. A., Grandbois, R., Kaplan, D. I., et al. (2017). Iodine and plutonium association with natural organic matter: a review of recent advances. Appl. Geochemistry 85, 121-127. doi: 10.1016/j.apgeochem.2016.11.009

Schindler, M., Legrand, C. A., and Hochella, M. F. (2015). Alteration, adsorption and nucleation processes on clay-water interfaces: mechanisms for the retention of uranium by altered clay surfaces on the nanometer scale. Geochim. Cosmochim. Acta 153, 15-36. doi: 10.1016/j.gca.2014.12.020

Schmidt, M., Lee, S. S., Wilson, R. E., Knope, K. E., Bellucci, F., Eng, P. J., et al. (2013). Surface-mediated formation of $\mathrm{Pu}(\mathrm{IV})$ nanoparticles at the muscovite-electrolyte interface. Environ. Sci. Technol. 47, 14178-14184. doi: $10.1021 /$ es4037258

Schumann, R. R., Zielinski, R. A., Otton, J. K., Pantea, M. P., and Orem, W. H. (2017). Uranium delivery and uptake in a montane wetland, north-central Colorado, USA. Appl. Geochem. 78, 363-379. doi: 10.1016/j.apgeochem.2017.01.001

Selvakumar, R., Ramadoss, G., Mridula, P. M., Rajendran, K., Thavamani, P., Ravi N, et al. (2018). Challenges and complexities in remediation of uranium contaminated soils: a review. J. Environ. Radioact. 192, 592-603. doi: 10.1016/j.jenvrad.2018.02.018

Shiryaev, A. A., Vlasova, I. E., Burakov, B. E., Ogorodnikov, B. I., Yapaskurt, V. O., Averin, A. A., et al. (2016). Physico-chemical properties of Chernobyl lava and their destruction products. Prog. Nucl. Energy 92, 104-118. doi: 10.1016/j.pnucene.2016.07.001

Shiryaev, A. A., Vlasova, I. E., Yapaskurt, V. O., Burakov, B. E., Averin, A. A., and Elantyev, I. (2018). Forensic study of early stages of the Chernobyl accident: story of three hot particles. J. Nucl. Mater. 511, 83-90. doi: 10.1016/j.jnucmat.2018.09.003

Skipperud, L., Strømman, G., Yunusov, M., Stegnar, P., Uralbekov, B., Tilloboev, H., et al. (2013). Environmental impact assessment of radionuclide and metal contamination at the former $\mathrm{U}$ sites Taboshar and Digmai, Tajikistan. J. Environ. Radioact. 123, 50-62. doi: 10.1016/j.jenvrad.2012.05.007

Smith, K. F., Bryan, N. D., Swinburne, A. N., Bots, P., Shaw, S., Natrajan, L. S., et al. (2015). U(VI) behaviour in hyperalkaline calcite systems. Geochim. Cosmochim. Acta 148, 343-359. doi: 10.1016/j.gca.2014.09.043

Stetten, L., Lefebvre, P., Le, P., Mangeret, A., Blanchart, P., Merrot, P., et al. (2020). Experimental redox transformations of uranium phosphate minerals and mononuclear species in a contaminated wetland. J. Hazard. Mater. 384:121362. doi: 10.1016/j.jhazmat.2019.121362

Szecsody, J. E., Truex, M. J., Qafoku, N. P., Wellman, D. M., Resch, T., and Zhong, L. (2013). Influence of acidic and alkaline waste solution properties on uranium migration in subsurface sediments. J. Contam. Hydrol. 151, 155-175. doi: 10.1016/j.jconhyd.2013.05.009

Tayal, A., Conradson, S. D., Kanzari, A., Lahrouch, F., Descostes, M., and Gerard, M. (2019). Uranium speciation in weathered granitic waste rock piles: an XAFS investigation. RSC Adv. 9, 11762-11773. doi: 10.1039/C9RA00961B

Vandenhove, H., Muikku, M., Vives i Batlle, J., Søvik, A., Lecomte-Pradines, C., Horemans, N. (2017). "COMET," in Final Report of the European Commission Funded COMET-RATE Project.

Vázquez-Campos, X., Kinsela, A. S., Bligh, M. W., Harrison, J. J., Payne, T. E., and Waite, T. D. (2017). Response of microbial community function to fluctuating geochemical conditions within a legacy radioactive waste trench environment. Appl. Environ. Microbiol. 83, 1-17. doi: 10.1128/AEM.00729-17

Veshchunov, M. S., Boldyrev, A. V., Shestak, V. E., and Mueller, K. (2008). Analysis of molten pool physico-chemical interactions and interpretation of the Phebus FP tests observations. Nucl. Eng. Des. 238, 1728-1742. doi: 10.1016/j.nucengdes.2007.10.015

Vitova, T., Pidchenko, I., Fellhauer, D., Bagus, P. S., Joly, Y., Pruessmann, T., et al. (2017). The role of the $5 \mathrm{f}$ valence orbitals of early actinides in chemical bonding. Nat. Commun. 8, 1-9. doi: 10.1038/ncomms16053

Xie, J., Liang, W., Lin, J., Zhou, X., and Li, M. (2018). Humic acids facilitated microbial reduction of polymeric $\mathrm{Pu}(\mathrm{IV})$ under anaerobic conditions. Sci. Total Environ. 610, 1321-1328. doi: 10.1016/j.scitotenv.2017.08.184

Zachara, J. M., Long, P. E., Bargar, J., Davis, J. A., Fox, P., Fredrickson, J. K., et al. (2013). Persistence of uranium groundwater plumes: contrasting mechanisms at two DOE sites in the groundwater-river interaction zone. J. Contam. Hydrol. 147, 45-72. doi: 10.1016/j.jconhyd.2013.02.001

Zavarin, M., Zhao, P., Joseph, C., Begg, J. D., Boggs, M. A., Dai, Z., et al. (2019). Hydrothermal alteration of nuclear melt glass, colloid formation, and plutonium mobilization at the Nevada National Security Site, U.S.A. Environ. Sci. Technol. 53, 7363-7370. doi: 10.1021/acs.est.8b 07199

Zhang, L., Zhou, J., Zhang, J., Su, J., Zhang, S., Chen, N., et al. (2016). Extraction of local coordination structure in a low-concentration uranyl system by XANES. J. Synchrotron Radiat. 23, 758-768. doi: 10.1107/S16005775160 01910

Zhao, P., Begg, J. D., Zavarin, M., Tumey, S. J., Williams, R., Dai, Z. R., et al. (2016). Plutonium(IV) and (V) Sorption to Goethite at subfemtomolar to micromolar concentrations: redox transformations and surface precipitation. Environ. Sci. Technol. 50, 6948-6956. doi: 10.1021/acs.est.6b 00605

Zhao, P., Zavarin, M., Leif, R. N., Powell, B. A., Singleton, M. J., Lindvall, R. E., et al. (2011). Mobilization of actinides by dissolved organic compounds at the Nevada Test Site. Appl. Geochem. 26, 308-318. doi: 10.1016/j.apgeochem.2010.12.004

Conflict of Interest: The authors declare that the research was conducted in the absence of any commercial or financial relationships that could be construed as a potential conflict of interest.

Copyright (C) 2020 Romanchuk, Vlasova and Kalmykov. This is an open-access article distributed under the terms of the Creative Commons Attribution License (CC BY). The use, distribution or reproduction in other forums is permitted, provided the original author(s) and the copyright owner(s) are credited and that the original publication in this journal is cited, in accordance with accepted academic practice. No use, distribution or reproduction is permitted which does not comply with these terms. 